\title{
Integrated Management of Fusarium Wilt-Root Knot Nematode Complex on Tomato in Central Highlands of Kenya
}

\author{
Waceke J. Wanjohi ${ }^{1}$, Geoffrey O. Wafula ${ }^{2}$ \& Charles M. Macharia ${ }^{2}$ \\ ${ }^{1}$ Department of Agricultural Science and Technology, Kenyatta University, P.O. Box 43844, Nairobi, Kenya \\ ${ }^{2}$ Koppert Biological Systems (K) Ltd P.O. Box 41852 -00100. Nairobi, Kenya \\ Correspondence: Waceke J. Wanjohi, School of Agriculture and Enterprise Development, Department of \\ Agricultural Science and Technology, Kenyatta University, P.O. Box 43844, Nairobi Kenya. Tel: \\ 254-208-710-901. E-mail: wanjohi.waceke@ku.ac.ke
}

Received: December 11, 2017 Accepted: December 29, 2017 Online Published: January 30, 2018

doi:10.5539/sar.v7n2p8

URL: https://doi.org/10.5539/sar.v7n2p8

\begin{abstract}
Tomato plays a critical role in meeting nutritional food requirements, generating income and creating employment for both the rural and urban populations in Kenya. However, its production is threatened by the Fusarium wilt caused by Fusarium oxysporum f.sp. lycopersici, root knot nematodes (Meloidogyne spp), Fusarium wilt-root-knot nematode complex and Tomato leaf miner (Tuta absoluta) among others. Yield losses of $80-100 \%$ in some instances, have been reported due to the Fusarium wilt - root knot nematode complex. Field experiments were set up in two sites (Kagio and Mwea) in Kirinyaga County in Central highlands of Kenya to evaluate the effectiveness of various Integrated Pest Management (IPM) packages for the management of fusarium wilt-root knot nematode disease complex in tomatoes. The trials were established in two seasons, the long rains (March - July 2016) and the short rains (September 2016- January 2017). The IPM packages tested were NatuGro system (a combination of soil improvers, plant biostimulants and Trichoderma harzianum T22), a fungicide (carbendazim), Nemix (Bacillus sp. based biocontrol agent) and bionematicide (Paecilomyces lilacinus T251) applied either singly or in combination. Root knot nematode (RKN) gall index, as a measure of nematode disease severity was assessed twice during the experimental period; at flowering and mid fruit stage, while severity of fusarium wilt was assessed using the vascular wilt rating scale of 0-5. Fusarium wilt incidence was evaluated biweekly from 2 weeks after transplanting by visual assessment of wilt symptoms and expressing them as a percentage of total number of plants per plot. Both total and marketable tomato yields were determined at the end of the experimental period (4 months after transplanting). Integrating NatuGro system, Carbendazim and P. lilacinus was most effective in reducing RKN disease severity and damage and improving tomato growth followed by NatuGro system applied singly. Fusarium wilt severity and incidence were low throughout the experimental period and in all the treatments in both experimental sites.
\end{abstract}

Keywords: Paecilomyces lilacinus, carbendazim, NatuGro system, Nemix, Venishine, NoPath and Trichoderma harzianum $T 22$

\section{Introduction}

Kenya is among Africa's leading producer of tomato with a total production of 445000 tonnes per annum (FAOSTAT, 2016). Tomatoes accounts for $14 \%$ of the total vegetable produced and $6.72 \%$ of the total horticultural crops produced in Kenya (GoK, 2012). Of the total tomato production, open field and greenhouse production account for 95\% and 5\%, respectively, (Seminis, 2007). In Kenya as at 2014, the top three leading counties in tomato production are Bungoma, Kirinyaga and Kajiado counties (HCDA, 2014). Besides generating income and earning foreign exchange, tomato plays a critical role in meeting nutritional food requirements and in creating employment for both the rural and urban populations (Sigei, Ngeno, Kibe, Mwangi, \& Mutai, 2014). Despite this significant contribution to poverty alleviation and economic growth, tomato yields are far below the genetic potential mainly due to diseases, insect and nematode pests. Among the insect pests, the tomato leaf miner (Tuta absoluta), whiteflies (Bemisia tabaci), thrips (Frankliniella occidentalis), African bollworm (Helicoverpa amigera) are the most important while among the diseases, bacterial wilt (Ralstonia solanacearum), early blight (Alternaria solani), late blight (Phytophthora infestans), fusarium wilt (Fusarium oxysporum f.sp. lycopersici) are the most important. Symptoms associated with $F$. oxysporum f.sp. lycopersici includes yellowing 
and drooping of the lower leaves. This often occurs on one side of the plant or on one shoot. Successive leaves yellow, wilt and die, often before the plant reaches maturity. As the disease progresses, growth is typically stunted and produce fewer smaller fruits or no fruits at all. Discoloration of the vascular system is characteristic of the disease and is generally used for its identification. Often, infected plants mature earlier and severe infection can lead to a $100 \%$ yield loss (Agrios, 2005).

Root knot nematode (Meloidogyne spp) pests contributes significantly to the low yields of tomatoes. Yield losses of up to $68 \%$ have been reported. Root galls that are 2-3 times the diameter of healthy root are the primary symptoms associated with RKN giving the roots a rough and clubbed appearance. In some cases, because of the proliferation of lateral roots the root system becomes dense and bushy. Above-ground symptoms include chlorosis, stunting and wilting during dry weather. Besides, the synergistic interaction between RKN and Fusarium wilt pathogens cause more severe losses than those caused by the fungus or nematode alone.

The Fusarium wilt-root-knot nematode complex is one of the most widely recognized and economically important disease complexes in the world (Manikandan \& Raguchander, 2014) as they both affect the function of the root system (water and mineral update). The two often infect tomato simultaneously, forming a complex that increases the incidence and severity of Fusarium wilt (Onkendia, Kariuki, Marais \& Moleleki, 2014). A study by Chindo, Khan and Erinle (1991) revealed that the presence of Meloidogyne spp greatly reduced resistance of tomato cultivars to the fusarium wilt. The presence of fungal survival structures (chlamydospores) that enhance its ability to persist in the soil for a long time and its wide host range makes its management fairly challenging (Blum \& Rodriques, 2004; Sudhamoy, Nitupama \& Adinpunya 2009; Moretti, Gilardi, Gullino \& Garibaldi 2008).

Various management options ranging from cultural, biological, resistant and chemical control have been used in an effort to manage the fusarium wilt- RKN complex in Kenya. These have various shortcomings, for instance, use of chemicals have negative impact on the environment leading to most of them being banned from the market (Onkendia et al., 2014; Kamal, Abo-Elyousr \& Hashem 2009). Use of crop rotation and fallowing are not feasible within smallholder crop production systems due to limited land resource, the polyphagus nature of RKN and the persistence of the fungus. The presence of pathotypes within the F. oxysporum f.sp. lycopersici and RKN population, makes the use of resistant varieties as a management option short lived ( Onkendia et al., 2014). These shortcomings make the search for alternative sustainable and environmental friendly methods of managing the Fusarium wilt- RKN disease complex imperative. Integrating plant essential oils, soil improvers, $T$. harzianum T22, bio-stimulants and colloidal silver in the management of soil borne diseases on tomato production systems in Kenya would provide such an alternative. Although literature is replete with information on the effect of some of these components applied singly, no data is available on integrating them on tomato production system in Kenya.

The objective of this study was therefore to determine the effect of IPM strategies in the management of Fusarium wilt-root-knot nematode disease complex within the smallholder farms in the Central Highlands of Kenya.

\section{Materials and Methods}

\subsection{Experimental Site}

On-farm experiments to determine the efficacy of various IDM strategies for the management of fusarium wilt-root-knot nematode complex were established on farmers' fields in Mwea and Kagio localities of Kirinyaga County in the central highlands of Kenya. Mwea is located in the southern part of Kirinyaga County and is within the Lower Midland Zone 4 (LM4) Agro Ecological Zone (Jaetzold \& Schmidt 1983). The area lies between Latitude $0^{\circ} 45^{\prime}$ South and Longitude $37^{\circ} 29^{\prime}$ East at an altitude of $1,050 \mathrm{~m}$ above sea level and has nitosols soils (Jaetzold \& Schmidt, 1983). The area experiences a bimodal rainfall with an average rainfall of about $850 \mathrm{~mm}$ and an average temperature of $22^{\circ} \mathrm{C}$. Kagio is on the North Eastern part of the county and lies between latitude $0^{\circ} 37^{\prime} 0^{\prime \prime} \mathrm{S}$ and longitude $37^{\circ} 15^{\prime} 0^{\prime \prime} \mathrm{E}$ at an altitude of $1248 \mathrm{~m}$ above sea level. It experiences a bimodal rainfall with an average annual rainfall of $1150 \mathrm{~mm}$ and a temperature of $20.6{ }^{\circ} \mathrm{C}$.

\subsection{Description of the Treatment Products}

The materials used for this study were NatuGro System consisting of 5 different components, a fungicide, a bionematicide, a biofungicide, an essential oil and colloidal silver (Table 1). 
Table 1. Description of experimental materials

\begin{tabular}{|c|c|c|}
\hline Product name & Product's role & Description of product \\
\hline 1. NatuGro systems & & \\
\hline 1.1. ProFunda & Soil improver & $\begin{array}{l}\text { Pellets of plant-based raw materials and seaweeds. } \\
\text { Contains } 7.5 \% \mathrm{~N} \text { in pure vegetable form, soft ground } \\
\text { potassium sulphate with magnesium }(4 \% \mathrm{~K} 2 \mathrm{O}) \text { and soft } \\
\text { ground rock phosphate }(2 \% \mathrm{P} 2 \mathrm{O} 5) \text {. }\end{array}$ \\
\hline 1.2. Trianum $P$ & Multiple roles & Trichoderma harzianum strain T22. \\
\hline 1.3. ProParva & Root Bio-stimulant & $\begin{array}{l}\text { A cold-pressed seaweed extract made from plant-based } \\
\text { raw materials with root stimulating properties. }\end{array}$ \\
\hline 1.4. ProFortum & $\begin{array}{l}\text { Vegetative growth } \\
\text { Bio-stimulant }\end{array}$ & $\begin{array}{l}\text { A seaweed extract with high concentration of amino acids } \\
\text { and peptides. }\end{array}$ \\
\hline 1.5. ProTerrum & $\begin{array}{l}\text { Fruit development } \\
\text { Bio-stimulant }\end{array}$ & $\begin{array}{l}\text { A cold-pressed extract from seaweed, humic acids and } \\
\text { herbs. It contains large quantities of organic compounds } \\
\text { such as amino acids, enzymes, plant hormones, various } \\
\text { sugars. }\end{array}$ \\
\hline $\begin{array}{l}\text { 2. Fungicide } \\
\text { (Carbendazim) }\end{array}$ & $\begin{array}{l}\text { Suppression of plant } \\
\text { parasitic fungi }\end{array}$ & $\begin{array}{l}\text { Carbendazim is a systemic and broad-spectrum } \\
\text { benzimidazole fungicide }\end{array}$ \\
\hline 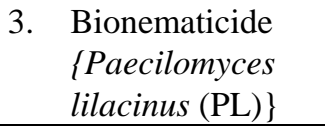 & $\begin{array}{l}\text { Suppression of plant } \\
\text { parasitic nematodes }\end{array}$ & $\begin{array}{l}\text { A biopesticide containing spores and mycelial fragments } \\
\text { of a naturally occurring Paecilomyces lilacinus fungus } \\
\text { used for control of plant parasitic nematodes }\end{array}$ \\
\hline $\begin{array}{l}\text { 4. Nemix (Bacillus } \\
\text { subtilis) }\end{array}$ & $\begin{array}{l}\text { Suppression of plant } \\
\text { pathogens }\end{array}$ & $\begin{array}{l}\text { Bacillus sp based commercial product -Bacillus subtilis a } \\
\text { soil inhabiting spore forming bacterium used in the } \\
\text { control of fungal diseases in soil and on foliage }\end{array}$ \\
\hline $\begin{array}{l}\text { 5. NoPath (Thyme } \\
\text { oil) }\end{array}$ & $\begin{array}{l}\text { Suppression of plant } \\
\text { pathogens }\end{array}$ & Thyme essential oils \\
\hline $\begin{array}{l}\text { 6. Venishine } \\
\text { (Colloidal silver) }\end{array}$ & $\begin{array}{l}\text { Suppression of plant } \\
\text { parasitic nematodes }\end{array}$ & $\begin{array}{l}\text { Colloidal silver; pure water mixed with ultra-tiny } \\
\text { nanoparticles of silver suspended inside, has plant pest } \\
\text { and pathogen preventive, therapeutic and restorative } \\
\text { properties. }\end{array}$ \\
\hline
\end{tabular}

\subsection{Treatments and Treatment Application Schedule}

The application method of the test materials and commencement of their application was as indicated in Table 2. Further, the rates at which they were applied, the intervals of their application and the number of application made during the experimental period are as specified below in Table 2 . 
Table 2. Treatment application schedule for Fusarium wilt-root-knot nematode complex management

\begin{tabular}{|c|c|c|c|c|}
\hline Treatment & $\begin{array}{l}\text { Application } \\
\text { Rate }\end{array}$ & Start of Application & $\begin{array}{l}\text { Interval } \\
\text { (Weeks) }\end{array}$ & $\begin{array}{l}\text { No. of } \\
\text { Applications }\end{array}$ \\
\hline Control & water only & - & - & - \\
\hline $\begin{array}{l}\text { Fungicide alone } \\
\text { (Carbendazim) }\end{array}$ & $20 \mathrm{ml} / 201$ & Sprayed 3 weeks after transplanting & 1 & 3 \\
\hline $\begin{array}{l}\text { Bionematicide } \\
\text { Paecilomyces lilacinus } \\
\text { NatuGro system }\end{array}$ & $10 \mathrm{ml} / 1$ & Drenched 3 weeks after transplanting & Monthly & 3 \\
\hline ProFunda & $300 \mathrm{~kg} / \mathrm{ha}$ & Band application transplanting & Once & \\
\hline Trianum-P & $1 \mathrm{~kg} / \mathrm{acre}$ & Drenched at transplanting & 4 & 3 \\
\hline ProParva: & $2 \mathrm{ml} / \mathrm{l}$ & Drenched at transplanting & 4 & 3 \\
\hline ProFortum & $2 \mathrm{ml} / 1$ & Sprayed 2 weeks after transplanting & 4 & 3 \\
\hline ProTerrum & $2 \mathrm{ml} / \mathrm{l}$ & Sprayed 2 weeks after transplanting & 4 & 4 \\
\hline Nemix Alone & $5 \mathrm{ml} / 1$ & Drenched 2 weeks after transplanting & 3 & 3 \\
\hline NatuGro+NoPath & $2 \mathrm{ml} / \mathrm{l}$ & Drenched 2 weeks after transplanting & Once & \\
\hline NatuGro+Veni Shine & $30 \mathrm{ml} / \mathrm{l}$ & Drenched 2 days before transplanting & Once & \\
\hline Fungicide + PL & As above & As above & As above & \\
\hline NatuGro+Nemix & As above & As above & As above & \\
\hline NatuGro+F+PL & As above & As above & As above & \\
\hline
\end{tabular}

\subsection{Test Crop and Experimental Design}

Tomato seedlings of variety Rambo F1, a susceptible variety to RKN (Mwangi, Kimenju, Narla \& Kariuki, 2017) was purchased from plant raisers (a professional propagator) and planted at the recommended spacing of $60 \mathrm{~cm}$ by $45 \mathrm{~cm}$. Experiments in the two sites were laid out in a Randomized Complete Block Design (RCBD) with three replications during the month of March to July 2016 and repeated in the month of September 2016 to January 2017. Plots measuring $25 \mathrm{~m}^{2}$ were used as experimental plots.

\subsection{Data Collection}

\subsubsection{Assessment of Tomato Yield}

Mature fruits were harvested from physiological maturity and continued for six weeks. The total weight per harvest per plot was recorded for each harvest. Un-marketable fruits especially very small (fruits weighing less than $50 \mathrm{~g}$ ), deformed or those damaged by pests and diseases were sorted out and weighed. Marketable yield was determined by getting the difference between total yield and un-marketable yield. Using the unit area per plot, the yield per plot was extrapolated to give yield in kilograms per hectare.

\subsubsection{Assessment of Disease Incidence and Severity}

Soil samples were collected per treatment before setting up of the experiment for pathological analysis to determine presence of the pathogen in the experimental fields.

Fusarium wilt disease incidence data was collected from 2 weeks after transplanting on a bi-weekly basis by visual assessment of wilt symptoms and recorded as a percentage of total number of plants per plot. Severity of fusarium wilt was assessed using Bletsos (2005) vascular wilt rating scale of $0-5$ where 0 to $5 ; 0=$ no symptom; $1=$ underground stem yellow-brownish discolored; $2=<30 \%$ aboveground stem brownish discolored; $3=$ stem bottom region decayed; 4 = stem darkly discolored and split; 5 =whole plant dead,

Data on RKN galling index were taken twice by destructive sampling of 3 plants at random from each plot (outside net plot) at flowering stage and mid fruiting stage. Roots were rated for galling on 0 to 4 scale (Barker, $1985)$, where $0=$ no galling $(0 \%), 1=$ light galling $(1 \%-25 \%), 2$ moderate galling $(26 \%-50 \%), 3=$ heavy galling $(51 \%-75 \%), 4=$ severe galling $(76 \%-100 \%$ galled roots $)$.

\subsection{Data Analysis}

All data collected was subjected to an Analysis of Variance (ANOVA) using GenStat statistical package $\left(15^{\text {th }}\right.$ edition). Treatment means were separated by Fischer Protected LSD at 5\% probability level. 


\section{Results}

\subsection{Season 1: March - July 2016}

\subsubsection{Tomato Yield}

There were highly significant differences $(p<0.001)$ in both marketable and total tomato yields among the treatments in the two trial sites (Table 3). The untreated plots and those treated with a combination of a fungicide and the P. lilacinus (PL) in Mwea sites had the lowest marketable yields while those treated with NatuGro and Venishine, NatuGro +NoPath, Nemix, NatuGro, Fungicide and P. lilacinus alone had some of the highest marketable yields in both sites (Table 3). In Mwea, there were no significant differences in marketable yield in plots treated with NatuGro alone or in combination with NoPath, Venishine or Fungicide $+P$. lilacinus implying that the addition of NoPath, Venishine or Fungicide $+P$. lilacinus to NatuGro did not have any significant effect on marketable and total yields (Table 3). Addition of Nemix to NatuGro, however, significantly reduced the efficacy of NatuGro to increase marketable yield in Mwea.

In Kagio study sites, plots treated with Nemix, Fungicide alone, NatuGro + NoPath , NatuGro + Nemix, supported some of the highest marketable yields that were significantly higher $(p<0.001)$ than those treated with NatuGro alone. Low marketable and total yields were recorded in the untreated, NatuGro+F+PL and F+PL treated plots while the highest marketable yield was reported in the Fungicide treated plots. The highest total yield was reported in the Nemix treated plots (Table 3)

Table 3. Mean ${ }^{\dagger}$ marketable and total yield $(\mathrm{kg} / \mathrm{ha})$ of tomatoes grown under different treatment combinations in Mwea and Kagio experimental sites; 120 days after planting. Season 1

\begin{tabular}{lllll}
\hline & Mwea & \multicolumn{3}{l}{ Kagio } \\
\cline { 2 - 5 } Treatment & $\begin{array}{l}\text { Marketable } \\
\text { Yield }(\mathrm{kg} / \mathrm{ha})\end{array}$ & $\begin{array}{c}\text { Total Yield } \\
(\mathrm{kg} / \mathrm{ha})\end{array}$ & $\begin{array}{l}\text { Marketable } \\
\text { Yield }(\mathrm{kg} / \mathrm{ha})\end{array}$ & $\begin{array}{l}\text { Total Yield } \\
(\mathrm{kg} / \mathrm{ha})\end{array}$ \\
\hline Fungicide (F) alone & $53125 \mathrm{~cd}$ & $58958 \mathrm{bc}$ & $50937 \mathrm{~d}$ & $55667 \mathrm{~d}$ \\
$P$. lilacinus $(\mathrm{PL})$ alone & $55625 \mathrm{~cd}$ & $58958 \mathrm{bc}$ & $43438 \mathrm{c}$ & $50313 \mathrm{c}$ \\
F + PL & $35625 \mathrm{a}$ & $41563 \mathrm{a}$ & $39583 \mathrm{a}$ & $46042 \mathrm{~b}$ \\
Nemix alone & $53438 \mathrm{~cd}$ & $59375 \mathrm{bc}$ & $50625 \mathrm{~d}$ & $56667 \mathrm{~d}$ \\
NatuGro alone & $55313 \mathrm{~cd}$ & $62188 \mathrm{c}$ & $42188 \mathrm{bc}$ & $50500 \mathrm{c}$ \\
NatuGro + NoPath & $56250 \mathrm{~cd}$ & $61562 \mathrm{c}$ & $48750 \mathrm{~d}$ & $55625 \mathrm{~d}$ \\
NatuGro + Nemix & $48438 \mathrm{~b}$ & $54688 \mathrm{~b}$ & $48125 \mathrm{~d}$ & $55000 \mathrm{~d}$ \\
NatuGro + VeniShine & $56875 \mathrm{~d}$ & $62813 \mathrm{c}$ & $43542 \mathrm{c}$ & $51250 \mathrm{c}$ \\
NatuGro + F+ PL & $52500 \mathrm{bc}$ & $58125 \mathrm{bc}$ & $38958 \mathrm{~b}$ & $45000 \mathrm{~b}$ \\
Control & $38750 \mathrm{a}$ & $45000 \mathrm{a}$ & $32813 \mathrm{a}$ & $39375 \mathrm{a}$ \\
\hline LSD & 4310 & 4734 & 3553 & 3582 \\
P-value & $<0.001$ & $<0.001$ & $<0.001$ & $<0.001$ \\
\hline
\end{tabular}

${ }^{\dagger}$ Mean for six replications.

${ }^{\sharp}$ Means with different letters are significantly different at $p=0.05$ according to Fischer

Protected LSD (Least Significant Difference).

\subsubsection{Galling Index}

There were highly significant differences $(p<0.001)$ in gall indices among treatments both at the flowering and mid fruit stage in Mwea (Table 4). Plants treated with Natugro alone or in combination with other treatments had the least galling indices that were significantly lower than the control or those treated with fungicide alone (Table 4).

In Kagio, there were highly significant differences $(p<0.001)$ in gall indices among treatments at the flowering stage but not at mid fruit stage (Table 3). Plants treated with Natugro alone or in combination with other treatments had the least galling indices that were significantly lower than the control or those treated with fungicide alone as was the case with Mwea (Table 4). 
Table 4. Mean ${ }^{\dagger}$ root galling index (GI) of tomatoes grown under different treatment combinations in Mwea and Kagio experimental sites; 120 days after planting-Season 1

\begin{tabular}{lllll}
\hline & Mwea & \multicolumn{3}{l}{ Kagio } \\
\cline { 2 - 5 } Treatment & $\begin{array}{l}\text { GI (Flowering } \\
\text { stage) }\end{array}$ & $\begin{array}{l}\text { GI (Mid } \\
\text { Fruit stage) }\end{array}$ & $\begin{array}{l}\text { GI (Flowering } \\
\text { stage) }\end{array}$ & $\begin{array}{l}\text { GI(Mid Fruit } \\
\text { stage) }\end{array}$ \\
\hline Fungicide (F) alone & $3.3 \mathrm{c}^{\ddagger}$ & $3.7 \mathrm{~d}$ & $3.0 \mathrm{~d}$ & $3.3 \mathrm{ab}$ \\
P. lilacinus (PL) alone & $1.7 \mathrm{ab}$ & $2.0 \mathrm{abc}$ & $2.7 \mathrm{~cd}$ & $3.0 \mathrm{ab}$ \\
F + PL & $2.0 \mathrm{~b}$ & $2.3 \mathrm{bc}$ & $2.3 \mathrm{bcd}$ & $2.3 \mathrm{ab}$ \\
Nemix alone & $2.0 \mathrm{~b}$ & $2.7 \mathrm{c}$ & $2.0 \mathrm{bc}$ & $3.0 \mathrm{ab}$ \\
NatuGro alone & $1.0 \mathrm{a}$ & $1.3 \mathrm{a}$ & $1.7 \mathrm{a}$ & $2.0 \mathrm{a}$ \\
NatGgro + NoPath & $1.7 \mathrm{ab}$ & $1.7 \mathrm{ab}$ & $2.0 \mathrm{bc}$ & $2.3 \mathrm{ab}$ \\
NatuGro + Nemix & $1.3 \mathrm{ab}$ & $1.7 \mathrm{ab}$ & $1.0 \mathrm{a}$ & $2.3 \mathrm{ab}$ \\
NatuGro + VeniShine & $1.3 \mathrm{ab}$ & $1.7 \mathrm{ab}$ & $1.0 \mathrm{a}$ & $2.0 \mathrm{a}$ \\
NatuGro + F + PL & $1.0 \mathrm{a}$ & $1.3 \mathrm{a}$ & $1.0 \mathrm{a}$ & $2.0 \mathrm{a}$ \\
Control & $3.0 \mathrm{c}$ & $3.7 \mathrm{~d}$ & $2.7 \mathrm{~cd}$ & $3.7 \mathrm{~b}$ \\
\hline LSD & 0.9 & 0.9 & 0.9 & 1.4 \\
P-value & $<0.001$ & $<0.001$ & $<0.001$ & 0.197 \\
\hline
\end{tabular}

${ }^{\dagger}$ Mean for six replications.

${ }^{\ddagger}$ Means with different letters are significantly different at $p=0.05$ according to Fischer

Protected LSD (Least Significant Difference).

\subsection{Season 2- September 2016- January 2017}

\subsubsection{Tomato Yield}

Though in general, tomato yield was not significantly different among the treatments in Mwea sites, NatuGro+F+PL recorded the highest marketable and total yield while the lowest yields were recorded in the PL treated plots (Figure 1)

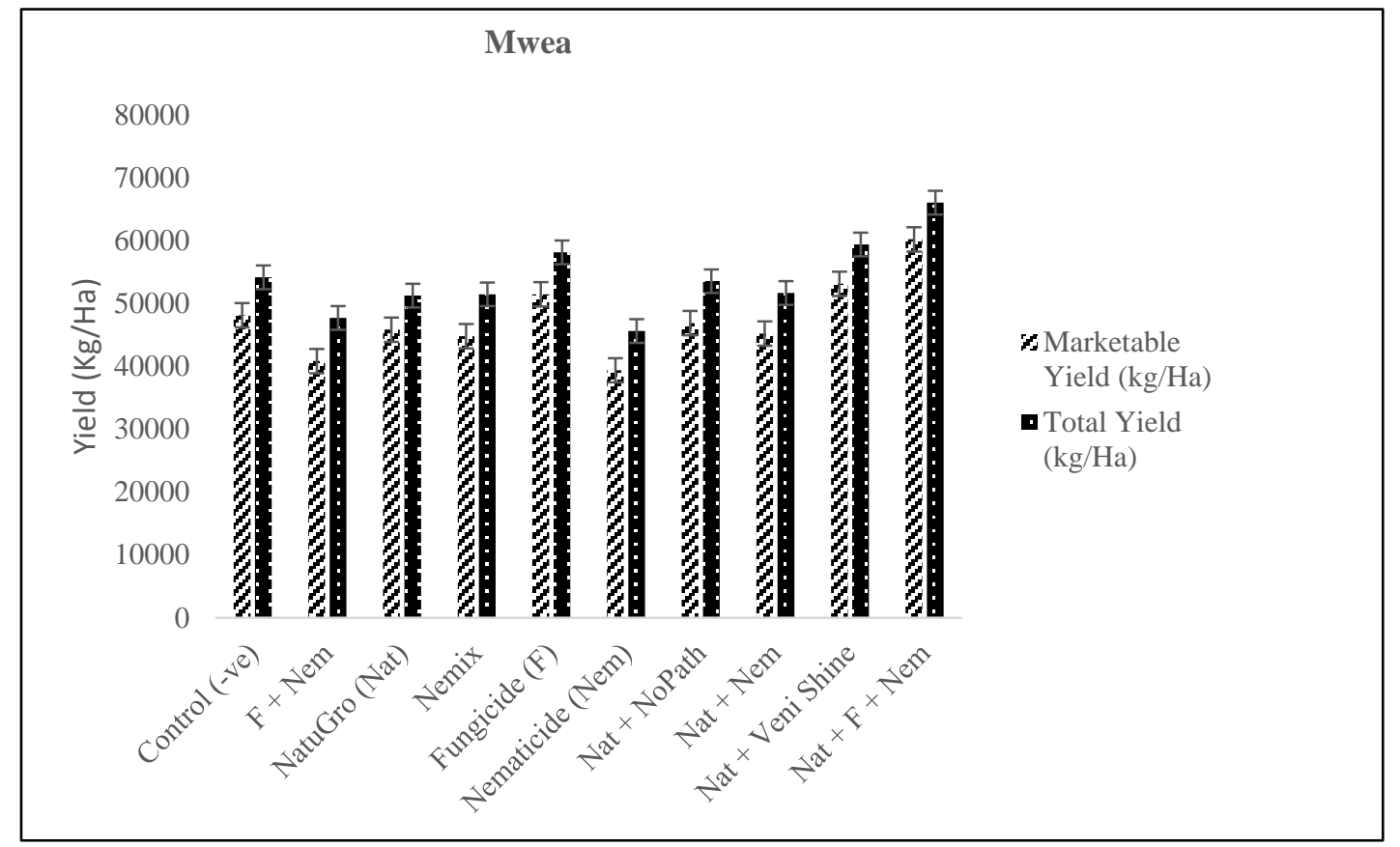

Figure 1. Mean ${ }^{\dagger}$ marketable and total yield $(\mathrm{kg} / \mathrm{ha})$ of tomatoes grown under different treatment combinations in Mwea experimental sites; 90 days after planting - Season 2

Similarly, in Kagio sites, there was no significant differences in tomato yields among the treatments. The lowest yields were recorded in the control plots while the highest yields were recorded in the P. lilacinus alone, or in NatuGro+ PL+ Fungicide treated plots (Figure 2). 


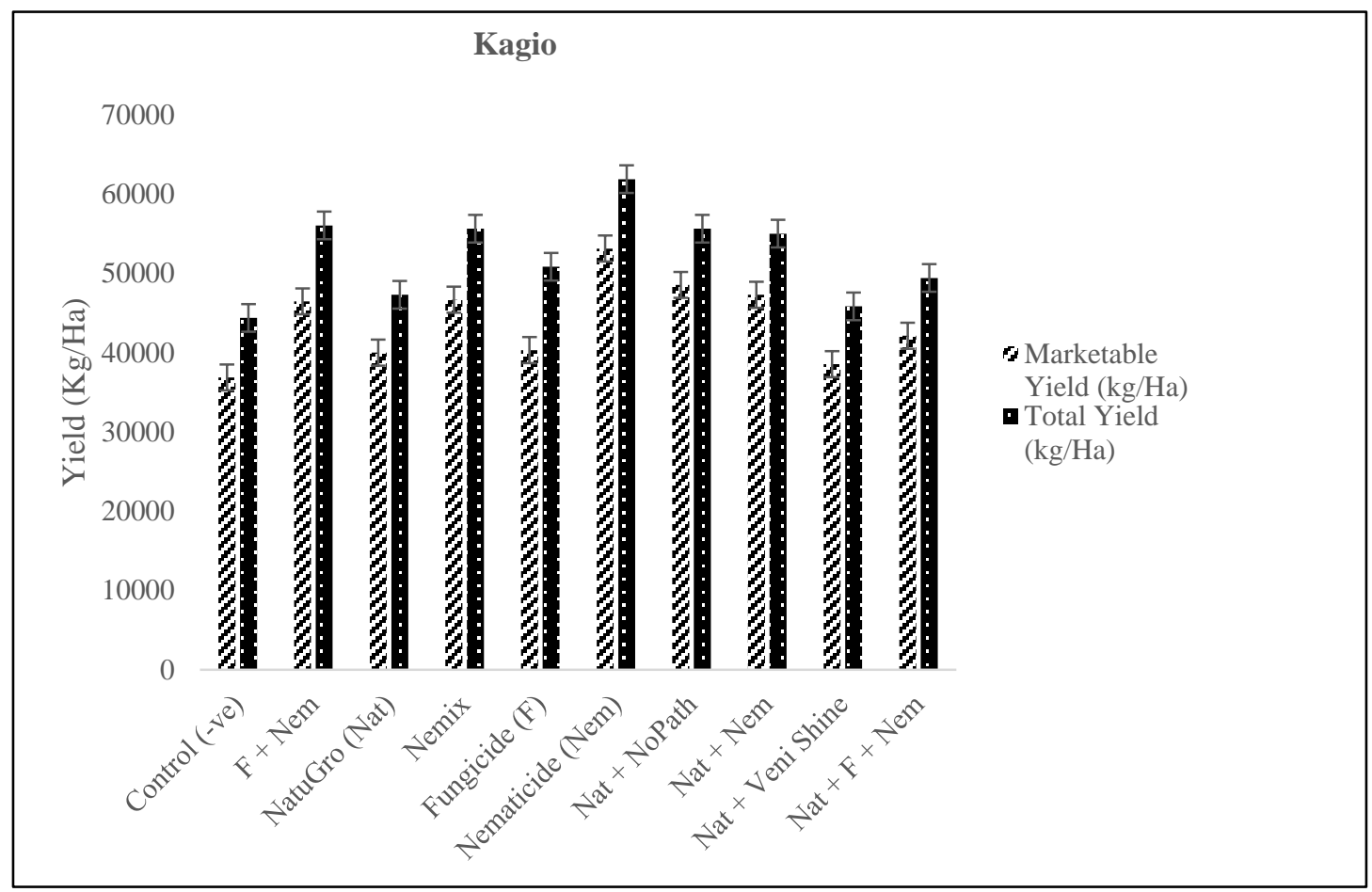

Figure 2. Mean ${ }^{\dagger}$ marketable and total yield (kg/ha) of tomatoes grown under different treatment combinations in Kagio experimental sites; 90 days after planting - Season 2

\subsubsection{Galling Index}

Across the sites, NatuGro+Fungicide+Nematicide significantly $(\mathrm{p}<0.05)$ reduced galling index both at flowering and mid fruit stage. Untreated (Control), Fungicide and P. lilacinus treated plots recorded some to the highest galling indices both in Mwea and Kagio (Figures 3 and 4).

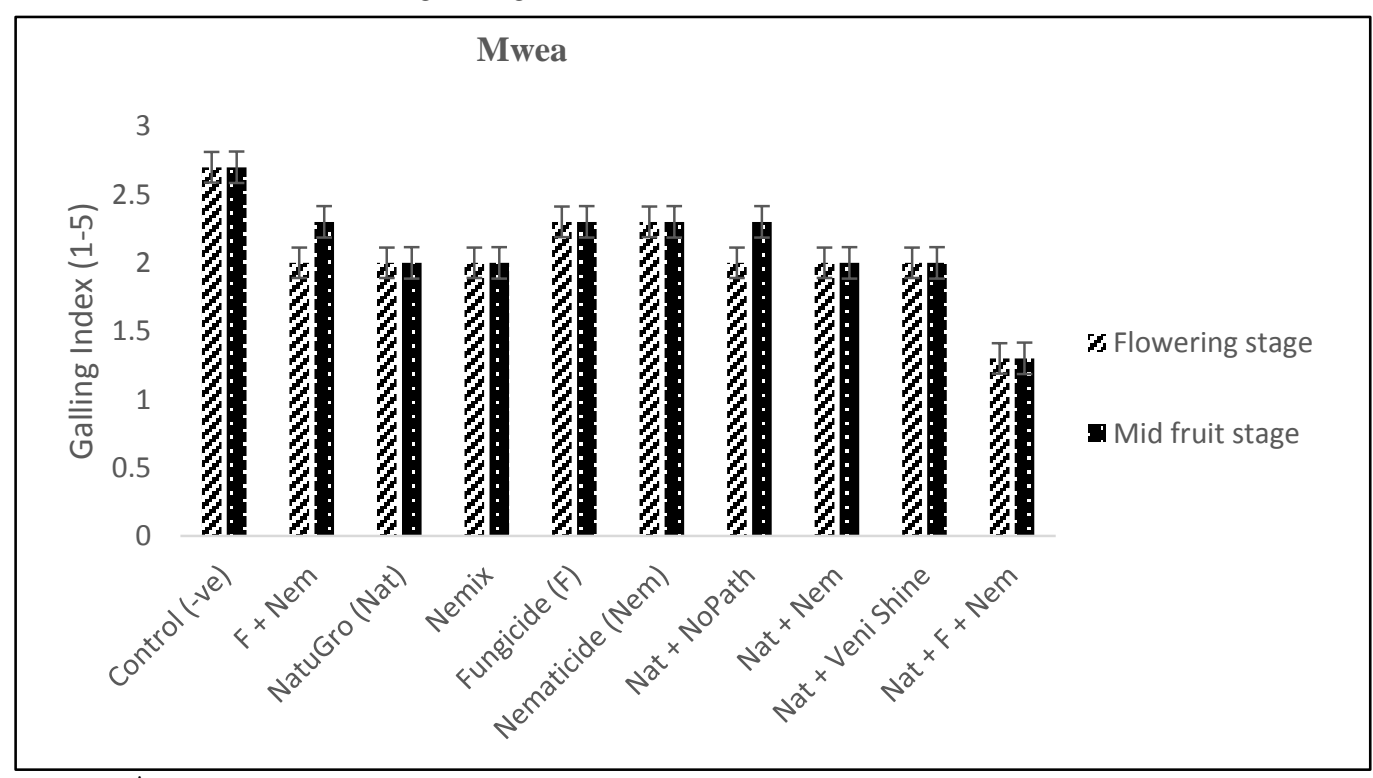

Figure 3. Mean ${ }^{\dagger}$ root galling index (GI) of tomatoes grown under different treatment combinations at flowering and mid fruit stage in Mwea experimental sites- Season 2 


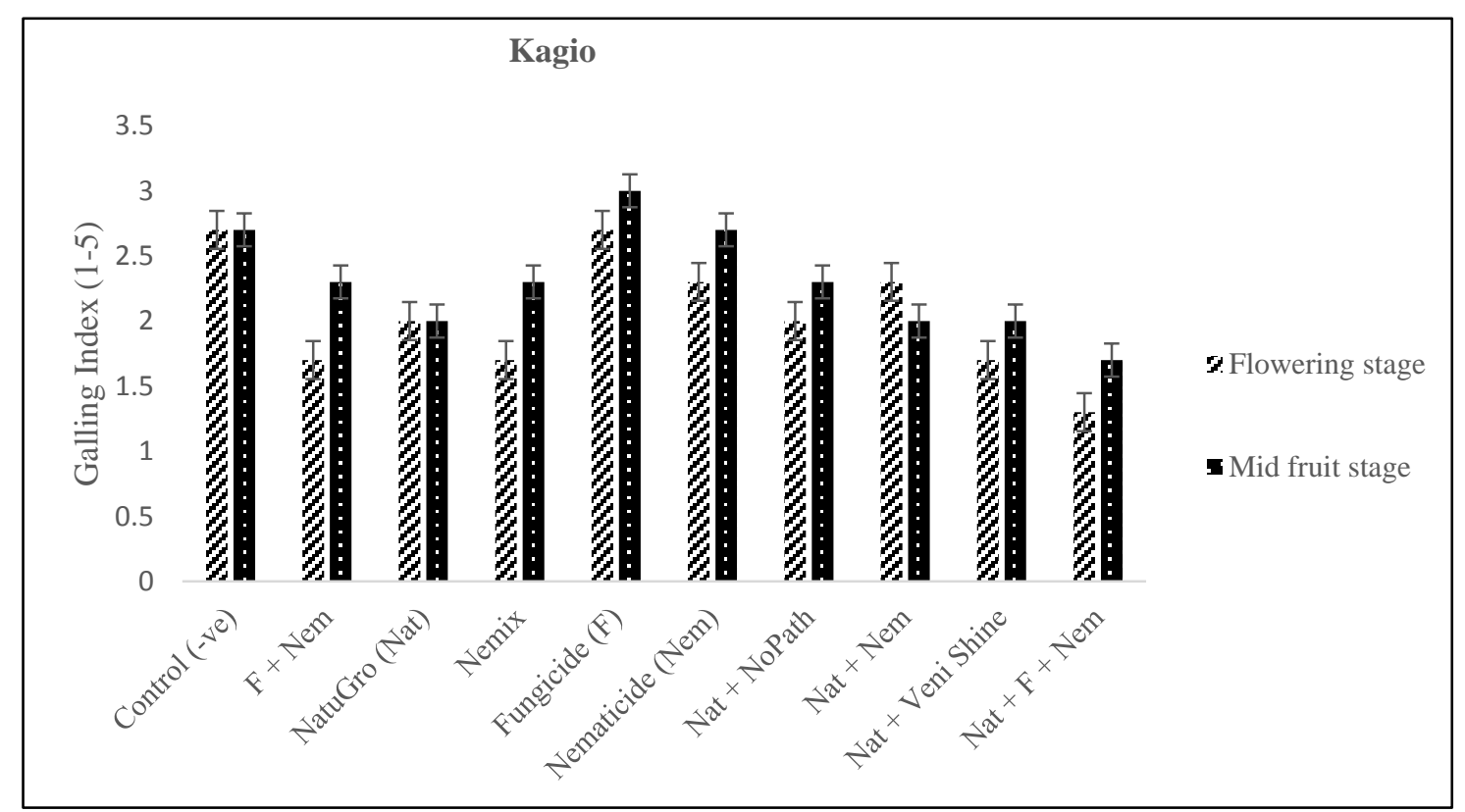

Figure 4. Mean ${ }^{\dagger}$ root galling index (GI) of tomatoes grown under different treatment combinations at flowering and mid fruit stage in Kagio experimental sites- Season 2

\section{Discussion}

In most cases, NatuGro applied both singly or in combination with other treatments supported some of the highest marketable and total tomatoes yields and significantly reduced disease severity of root knot nematode. Components of NatuGro namely the soil improvers, plant biostimulants and Trianum (Trichoderma harzianum T22) (Table 1) enhances plant growth and its resistance to diseases. Several Trichoderma sp. have been reported to suppress soil borne disease fungi including Fusarium sp. and plant parasitic nematodes (Siddiqui, Ehteshami-Haque \& Ghaffer, 1999). Trichoderma species are known to produce secondary metabolites that act on the soil borne pathogens through parasitism and/or antibiosis (Belanger, Dufour, Caron \& Benhamou, 1995; Di Pietro, 1995 Cotes, Lepoivre \& Semal, 1996). Waafa, Haaga and Amin (2001) also reported a reduction in fungal -nematode disease complex and an increase in plant growth parameters with the application of $T$. harzianum. Further, T. harzianum T22 and plant growth promoting agents have been reported to induce resistance in plants (Siameto, Okoth, Amugune, \& Chege, 2010; Samia \& Abbas, 2012; Njoroge 2014; Kipng'eno, Losenge, Maina, Kahangi \& Juma, 2015). This beneficial fungus has also been reported to be effective in the management of the fusarium wilt fungus and RKN (El-Shennawy, Khalifa, Ammar, Mousa, \& Hafez 2012). There is need to elucidate the mechanisms involved in suppression of disease by NatuGro and the effects of the edaphic factors on the efficacy

Application of plant essential oils are also reported to induce resistance through increased phenolic compounds (Cetintas \&Yarba, 2010). The oils are known to have antimicrobial properties (Kalemba \& Kunicka, 2003) and have been reported to control root-knot nematode, Meloidogyne incognita Race 2 (Cetintas \& Yarba, 2010) and bacterial speck (Pseudomonas syringae) on tomato (Siddiqui et al., 1999). Plant essential oils, apart from contributing to diseases and pest management, play an important role as internal physiological regulators and thereby promote plant growth (Lattanzio V., Lattanzio, M., \& Cardinali 2006). Similarly, application of bio-stimulants are reported to be elicitors of induced resistance through increased levels of phenolic compounds (Westphal, 2011; Zbigniew, Micha \& Dzida 2011).

Soil improvers play a critical role in restoring ecological balance in heavily cultivated soils which are usually prone to infestation by soil-borne pathogens (Siameto et al., 2010). Some bio-stimulants that work as growth promoting agents elicit induced plant resistance in the areas where they are applied (Mehrafarin, Qavami, \& Tahmasebi, 2015). The induced resistance plays an important role in pest management.

Bacillus subtilis competes with other microorganisms by producing antibiotics that either kill competitors or reduce their growth rate. It is reported to induce systemic acquired resistance (SAR) against bacterial pathogens, whereby the plant's defenses are triggered prior to pest incursion. In addition, the bacterium, hinders spore germination in plant pathogens and prevents pathogens from attaching to the plant. This allows it to fill a void in 
the rhizosphere and/or foliage of plants where damaging pathogens may take up residence (Nunes, Monteiro, \& Pomela, 2010; Kim S., Jung, Lamsal, Kim, Y., Min, \& Lee, 2012; Kipng'eno et al., 2015).

Spraying colloidal silver on the surface of plants infected with plant pathogens and pests suffocates the pathogens to death by inactivating the oxygen metabolism enzyme needed to sustain the plant pathogens and pests without affecting the plants (Kim et al., 2012). Silver nanoparticles applied on spring onion roots were reported to control Sclerotium cepivorum fungal infections and increase the fresh and dry weight of the onions (Lamsal, Kim S., Jung, Kim,Y.,\& Lee 2011; Kim et al., 2012).

The untreated and fungicide+ P. lilacinus treated soils supported some of the lowest tomato yields and some of the highest nematode disease severity. The effect of Carbendazim on P. lilacinus ability to reduce RKN population need to be investigated.

\section{Conclusion}

This study showed that application of NatuGro reduced the effect of fusarium wilt-root-knot nematode disease complex on tomato yield. Application of NatuGro reduced significantly root galling index and recorded an increase in tomato yield. Combining NatuGro, Carbendazim and P. lilacinus in an integrated approach has the potential to manage the Fusarium RKN disease complex in tomato disease management. The IPM packages that demonstrated highest efficacy for the management of the Fusarium wilt-root knot nematode disease complex management were NatuGro alone and NatuGro + Fungicide + P. lilacinus. Further studies needs to be conducted to understand the effect of edaphic factors on the efficacy of NatuGro.

\section{Acknowledgements}

This research project was carried out with financial support from the Food and Business Applied Research Fund (ARF) under the Netherlands Organization for Scientific Research (NWO) WOTRO Science for Global Development.

\section{References}

Barker, K. R. (1985). Nematode extraction and bioassays. In K. R. Barker, Carter, C. C., \& Sasser, J. N. (Eds.), An Advanced Treatise on Meloidogyne, Vol. 2. Methodology (pp. 19-35). Raleigh; North Carolina State University Graphics

Belanger, R.R., Dufour, N., Caron, J., \& Benhamou, N. (1995). Chronological events associated with the antagonistic properties of Trichoderma harzianum against Botrytis cinerea. Indirect evidence for sequential role of antibiosis and parasitism. Biocontrol Science and Technology, 5, 41-53. https://doi.org/10.1080/09583159550040006

Bletsos, F. A. (2005). Use of grafting and calcium cyanimide as alternatives to methyl bromide soil fumigation and their effects on growth, yield, quality and fusarium wilt control in melon. Journal of Phytopathology 153(3), 155-161. https://doi.org/10.1111/j.1439-0434.2005.00945.x

Blum L. E. B., \& Rodriguez-Kabana, R. (2004). Effect of organic amendments on sclerotial germination, mycelial growth, and Sclerotium rolfsii-induced diseases. Fitopatologia Brasileira, 29, 66-74. https://doi.org/10.1590/S0100-41582004000100010

Cetintas, R., \& Yarba, M. M. (2010). Nematicidal Effects of Five Plant Essential Oils on the Southern Root-Knot Nematode, Meloidogyne incognita, Race 2. Journal of Animal and Veterinary Advances, 9(2), 22-225. https://doi.org/10.3923/javaa.2010.222.225

Chindo, P. S., Khan, F. A., \& Erinle, I. D. (1991). Reaction of three tomato cultivars to two vascular diseases in presence of the root-knot nematode, Meloidogyne incognita race 1. Crop Protection, 10, 62-64. https://doi.org/10.1016/0261-2194(91)90028-P

Cotes, A. M., Lepoivre, P., \& Semal, J. (1996). Correlation between hydrolytic enzyme activities measured in bean seedlings after Trichoderma koningii treatment combined with pre-germination and the protective effect against Pythium splendens. European Journal of Plant Pathology, 102, 497-506. https://doi.org/10.1007/BF01877144

Di Pietro, A. (1995). Fungal antibiosis in biocontrol of plant disease. In K.M.M. Dakshini \& Einhelling, F.A. (Eds.), Allelopathy: Organisms, Processes and Applications (pp. 271-279) American Chemistry Society, Washington DC.

El-Shennawy, M. Z., Khalifa, E. Z., Ammar, M. M., Mousa, E. M., \& Hafez, S. L. (2012) Biological control of the disease complex on potato caused by root-knot nematode and Fusarium wilt fungus. Nematology 
Mediterrenean, 40, 169-172

Jaetzold, R., \& Schmidt, H. (1983). Farm Management Handbook of Kenya. Vol III Ministry of Agriculture Nairobi Kenya.

FAOSTAT, (2012). Food and Agriculture Organisation of the United Nation.www.fao.org. Accessed on $15^{\text {th }}$ January 2018

Government of Kenya (GoK). (2012). National Horticulture Policy. Ministry of Agriculture, Kilimo House, Nairobi. www.kilimo.go.ke. Accessed on $7^{\text {th }}$ April 2016

Horticultural Crop Development (HCD) (2014). Horticultural Crops Directorate, Horticulture validated data 2014.

Kalemba, D., \& Kunicka, A. (2003). Antibacterial and Antifungal Properties of Essential Oils. Current Medicinal Chemistry, 10, 813-829. https://doi.org/10.2174/0929867033457719

Kamal, A. M., Abo-Elyousr, M., \& Hashem, E. H. A. (2009). Integrated control of cotton root rot disease by mixing fungal biocontrol agents and resistance inducers. Crop Protection, 28(4), 95-301.

Kim, S. W., Jung, J. H., Lamsal, K., Kim, Y. S., Min, J. S., \& Lee, Y. S. (2012). Antifungal Effects of Silver Nanoparticles (AgNPs) against Various Plant Pathogenic Fungi. Mycobiology, 40(1), 53-58. https://doi.org/10.5941/MYCO.2012.40.1.053

Kipng'eno, P., Losenge, T., Maina, N., Kahangi, E., \& Juma, P. (.2015). Efficacy of Bacillus subtilis and Trichoderma asperellum against Pythium aphanidermatum in tomatoes. Biological Control, 90, 92-95. https://doi.org/10.1016/j.biocontrol.2015.05.017

Lamsal, K., Kim, S. W., Jung, J. H., Kim, Y. S., Kim, K. S., \& Lee, Y. S. (2011). Application of silver nanoparticles for the control of Colletotrichum species in vitro and pepper anthracnose disease in field. Mycobiology, 39(3), 194-199. https://doi.org/10.5941/MYCO.2011.39.3.194

Lattanzio, V., Lattanzio, M. T., \& Cardinali, A. (2006). Role of polyphenols in the resistance mechanisms of plants against fungal pathogens and insects. Phytochemistry, 37, 23-67

Manikandan, R., \& Raguchander, T. (2014). Prevalence of tomato wilt disease incited by soil borne pathogen Fusarium oxysporum f. sp. lycopersici (Sacc.) in Tami Nadu. International Journal of Tropical Agriculture, 32(1), 279-283

Mehrafarin, A., Qavami, N., \& Tahmasebi, Z. (2015). Phytochemical and Morpho-physiological Responses of Lemon Balm (Melissa officinalis L.) to Biostimulants Application. Journal of Medicinal Plants, 14(55), $29-42$.

Moretti, M., Gilardi, G., Gullino, M. L., \& Garibaldi, A. (2008). Biological control potential of Achromobacter xylosoxydans for suppressing Fusarium wilt of tomato. International Journal of Botany, 4, 369-375. https://doi.org/10.3923/ijb.2008.369.375

Mwangi, M. W., Kimenju, J. W., Narla, R. D., \& Kariuki, G. M. (2017). Evaluation of selected tomato cultivars reaction to infestation with Meloidogyne javanica in greenhouse conditions. International Journal of Agronomy and Agricultural Research, 11(3), 17-25

Njoroge, H. W. (2014). Management of Root Knot nematode and Fusarium wilt of tomato by pre-treatment os seedlings with chemicals and biological agents. MSc Thesis UoN.

Nunes, H. T., Monteiro, A. C., \& Pomela, A. W. V. (2010). Use of microbial and chemical agents to control Meloidogyne incognita in soybean. Acta Science and Agronomy, 32(3). http://dx.doi.org/10.4025/actasciagron.v32i3.2166

Onkendia, E. M., Kariuki, G. M., Marais, M., \& Moleleki, L. N. (2014). The threat of root-knot nematodes (Meloidogyne spp.) in Africa: a review. Plant Pathology, 63, 727-737. https://doi.org/10.1111/ppa.12202

Samia, A. A., \& Abbas, S. M. (2012). Application of Trichoderma harziunum T22 as a biofertilizer supporting maize growth. African Journal of Biotechnology, 11(35), 8672-8683

Seminis Kenya. (2007). Retrieved from: http://www.freshplaza.com/news February 2017

Siameto, E. N., Okoth, S., Amugune, N. O., \& Chege, N. C. (2010). Antagonism of Trichoderma harzianum isolates on soil borne plant pathogenic fungi from Embu District, Kenya. Journal of Yeast Fungal Research, 1, 47-54. 
Siddiqui, I. A., Ehteshamul-Haque, S., \& Ghaffer, A. (1999). Root dip treatment with Pseodomonas aeruginosa and Trichoderma spp. in the control of root rot-root knot disease complex in chili. Pakistan Journal of Nematology, 17, 67-75.

Sigei, K. G., Ngeno, K. H., Kibe, M. A., Mwangi, M. M., \& Mutai, C. M. (2014). Challenges and strategies to improve tomato competitiveness along tomato value chain in Kenya. International Journal of Business and Management, 9(9), 230-245.

Sudhamoy, M., Nitupama, M., \& Adinpunya, M. (2009). Salicylic acid induced resistance to Fusarium oxysporum f. sp. lycopersici in tomato. Plant Physiology and Biochemistry, 47, 642-649. https://doi.org/10.1016/j.plaphy.2009.03.001

Waafa, M., Haagag, W., \& Amin, A. W. (2001). Efficiency of Trichoderma species in control of fusarium rot, root knot and reniform nematode disease complex on sunflower. Pakistan Journal of Biological Sciences, 4(6), 679-683. https://doi.org/10.3923/pjbs.2001.679.683

Westphal, A. (2011). Sustainable Approaches to the Management of Plant-parasitic Nematodes and Disease Complexes. Journal of Nematology, 43(2), 122-125.

Zbigniew, J., Micha, Z., \& Dzida, K. (2011). Changes in the chemical composition of the rhizosphere of tomato grown on inert substrates in a prolonged cycle. Journal of Elementary Sciences.

\section{Copyrights}

Copyright for this article is retained by the author(s), with first publication rights granted to the journal.

This is an open-access article distributed under the terms and conditions of the Creative Commons Attribution license (http://creativecommons.org/licenses/by/3.0/). 